Article

\title{
Mercury Exposure and Health Problems of the Students Using Skin-Lightening Cosmetic Products in Makassar, South Sulawesi, Indonesia
}

\author{
Hasriwiani Habo Abbas ${ }^{1, *}$, Masayuki Sakakibara ${ }^{2,3}$, Koichiro Sera ${ }^{4}$, Nurgahayu ${ }^{1}$ \\ and Ella Andayanie 1 \\ 1 Faculty of Public Health, Universitas Muslim Indonesia (UMI), Gedung FKM UMI, Jl. Urip Sumahorjo Km 5, \\ Makassar Sulawesi Selatan 90231, Indonesia; nurgahayu.nurgahayu@umi.ac.id (N.); \\ ella_andayanie@yahoo.com (E.A.) \\ 2 Department of Earth Science, Graduate School of Science and Engineering, Ehime University, \\ 2-5 Bunkyo-cho, Matsuyama, Ehime 790-8577, Japan; sakakibara.masayuki.mb@ehime-u.ac.jp \\ 3 Faculty of Collaborative Regional Innovations, Ehime University, 2-5 Bunkyo-cho, Matsuyama, \\ Ehime 790-8577, Japan \\ 4 Cyclotron Research Center, Iwate Medical University, 348-58 Tomegamori, Takizawa, Iwate 020-0137, Japan; \\ ksera@iwate-med.ac.jp \\ * Correspondence: hasriwianihabo.abbas@umi.ac.id or haboabbashasriwiani@yahoo.com; \\ Tel.: +62-822-7145-8731
}

Received: 28 May 2020; Accepted: 22 July 2020; Published: 24 July 2020

\begin{abstract}
Despite legal and safety issues, skin-lightening cosmetic products-including hazardous mercury-containing cosmetics-are in increasing demand in Indonesia. Perceptions of beauty may result in desires to have lighter skin tones, regardless of the safety of these cosmetics, which block the production of melanin and thus lighten skin tone. This study investigated $\mathrm{Hg}$ exposure of students using skin-lightening cosmetics and assessed the health issues. A total of 105 female students were given a questionnaire regarding their use of cosmetics; a further 43 students formed a non-cosmetic-user control group. Their scalp hair and cosmetic products were analyzed by particle-induced X-ray emission (PIXE) spectroscopy. The geometric-mean hair $\mathrm{Hg}$ concentration for the cosmetics-using students was $6.7 \mu \mathrm{g} \mathrm{g}^{-1}$-three times that of the control group $\left(2.3 \mu \mathrm{g} \mathrm{g}^{-1}\right)$. Of twenty-seven cosmetic samples were analyzed, twenty had $\mathrm{Hg}$ concentrations of $0.12-7834.4 \mu_{\mathrm{g} \mathrm{g}}{ }^{-1}$ (mean $554.6 \mu \mathrm{g} \mathrm{g}^{-1}$ ), and seven had no detectable $\mathrm{Hg}$. The hair $\mathrm{Hg}$ concentrations exhibited a statistically significant correlation with cosmetic $\mathrm{Hg}$ concentration. The health assessments indicated only rigidity \& ataxia and irregular eye movement were prevalent in the cosmetic-using students with less than $7 \%$ occurrences.
\end{abstract}

Keywords: mercury exposure; skin-lightening cosmetic products; health problems

\section{Introduction}

Skin-lightening cosmetics are commonly used by women who perceive lighter skin as a beauty enhancement-regardless of the ingredients of the cosmetics. In Asia, the sale of such products has increased annually by up to $20 \%$ from $1997-2003$. In Thailand, their sales contributed more than $60 \%$ of the country's annual USD100 million facial skincare market [1]. As a populous country, Indonesia is a promising market for such products because of the increasing demand and cosmetic trends [2]. There are, however, legal requirements and safety concerns. Toxic ingredients, such as mercury have been identified in cosmetic products [3-6]. The Indonesian National Agency of Drug and Food Control works to overcome this problem as cosmetics containing various toxic ingredients spread widely in the market $[7,8]$. 
In cosmetic products, $\mathrm{Hg}$ commonly occurs as inorganic salts such as mercurous chloride (calomel), mercuric chloride and mercuric oxide. In cosmetic creams, such $\mathrm{Hg}$ compounds block the production of melanin, which produces color in hair and skin [9]. Other chemical compounds may be as effective as Hg salts, but manufacturers prefer the salts because they are relatively inexpensive [10]. The skin absorbs inorganic $\mathrm{Hg}$ from cosmetic creams through transepidermal [11] and transappendageal routes, with the latter involving transfer via sebaceous glands, sweat glands and hair follicles [12], through which $\mathrm{Hg}$ ultimately accumulates in the scalp hair.

Prolonged exposure to $\mathrm{Hg}$ through repeated cosmetics applications may lead to the impairment of brain, nervous and renal systems [13]. Mercury affects the human body by disrupting immune functions and microtubule formation, altering cell membrane integrity, disturbing or restraining enzyme systems, shifting the balance of intracellular calcium and membrane potentials and constraining protein and DNA synthesis [14]. The primary adverse effect of inorganic Hg exposure is kidney damage [13,14], including renal tubular necrosis and/or autoimmune glomerulonephritis.

Mercury intoxication often presents as nonspecific symptoms [15], with similar health effects to those of other chronic conditions. Clinical presentations are highly dependent on dose, duration and the form of exposure $[4,16]$. With chronic exposure, the initial presentation involves light tremor in extremities that eventually propagates to the entire limb [15]; with three classic chronic symptoms being tremor, gingivitis and erethism (a constellation of neuropsychiatric symptoms including insomnia, shyness, memory loss, emotional instability, depression, anorexia, vasomotor disturbance, uncontrolled perspiration and blushing) [4].

Most cosmetics users are female; Hg exposure is of particular concern for women of reproductive age because $\mathrm{Hg}$ is a known teratogenic agent that can cross the placenta wall [17]. However, many women in their twenties use cosmetics as part of their daily routine, and most lack knowledge on cosmetic ingredients or Hg toxicity [18]. Hazardous skin-lightening products are therefore widely used with limited awareness of their potential health effects. This study investigated Hg exposure of female students who use skin-lightening cosmetic products and their health problems related to Hg intoxication.

Investigations of health problems associated with $\mathrm{Hg}$ intoxication due to topical cosmetic creams has focused previously on allergic contact dermatitis, nephropathy and the impairment of the liver, cardiovascular and reproductive systems. Only few investigations associated inorganic mercury intoxication with neurological symptoms due to low passage through the blood-brain barrier. In attempts to determine potential neurotoxicity, some experimental studies with animals have shown that inorganic mercury crosses the placenta barrier and can accumulate in the brain [19] with cerebral dysfunction being observed [20-22]. The student cohort was therefore checked for neurological symptoms. Moreover, inorganic $\mathrm{Hg}$ exposure from cosmetics occurs over prolonged time intervals, so cosmetic products and their users should be monitored for $\mathrm{Hg}$ exposure as part of public health surveillance.

\section{Materials and Methods}

\subsection{Cosmetic and Hair Samples Collection}

The study involved 148 female students from two universities in Makassar, of whom 105 were skin-lightening cosmetic users and 43 were a control group of non-users. The control group students were from the same two universities, in the same age range and of the same dietary range. The students were interviewed and given a questionnaire regarding their socio-demography, dietary habits, cosmetic brand names, duration and frequency of cosmetic use and cosmetics consumption per month. The students used 27 brands of skin-lightening cosmetic products that were used exclusively on facial skin. All participants voluntarily provided scalp hair samples for analysis. The study was approved by the local government of Makassar District and the ethical committee of the author's 
institution. Before sampling began, the students were provided with an explanation to ensure they understood the purpose of the study, and consent forms were signed.

\subsection{Analytical Procedure}

Skin-lightening cosmetic product samples (Figure 1) were obtained from the students. Small amounts of cosmetic cream were placed in a compact powder case and delivered to the laboratory for analysis. The cream was mixed with acetone, a 1000 ppm indium solution was added and the mixture was vortex-homogenized. Droplets were placed on a thin backing film ( $4 \mu \mathrm{m}$ Prolene) and evaporated to dryness.

Hair samples comprised scalp hair cut into four $\sim 3 \mathrm{~cm}$ sections from root to tip. To remove organic materials, the hair samples were cleaned with Milli-Q water in an ultrasonic bath for 5 min, then with acetone for $5 \mathrm{~min}$, before further washing with Milli-Q water. Finally, samples from eight strands of hair per student were attached in parallel to a sample holder and dried at room temperature.

Mercury concentrations in cosmetics and hair samples were determined by particle-induced X-ray emission (PIXE) spectroscopy at the Cyclotron Research Center, Iwate Medical University, Takizawa city, Japan, with a $2.9 \mathrm{MeV}$ proton beam collimated to 6-mm-diameter, the sample set at an angle of $35^{\circ}$ to the beam axis, and with characteristic X-ray detection by a Si (Li) detector.
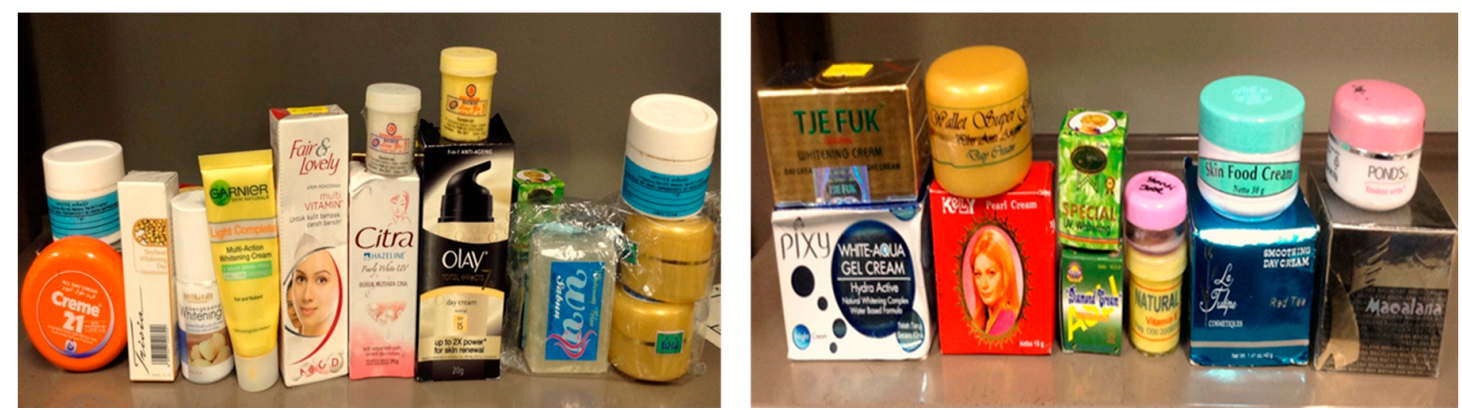

Figure 1. Skin-lightening cosmetic products used by the students.

\subsection{Health Assessment}

Health assessments were performed after the $\mathrm{Hg}$ contents of hair samples had been determined. The 64 students whose scalp hair contained $>5$ ppm Hg were invited to be tested for Hg intoxication symptoms, and 15 students agreed to the tests. The control-group students with hair $\mathrm{Hg}$ contents at the alert level (1-5 ppm) were invited to take the same test, and 17 students agreed, but 2 of them were excluded because of their $38^{\circ} \mathrm{C}$ body temperature. Ten neurological symptoms [23] were checked by a physician following protocols for the environmental and health assessment of $\mathrm{Hg}$ suggested by the United Nations Industrial Development Organization [24]: (a) bluish discoloration of gums; (b) rigidity and ataxia (walking or standing); (c) alternating movements or dysdiadochokinesia; (d) irregular eye movements or nystagmus; (e) reduced field of vision; (f) knee-jerk and biceps reflexes; (g) Babinski and labial reflex; (h) salivation and dysarthria; (i) sensory examination; and (j) tremor of tongue, eyelids, finger to nose, pouring and posture holding. Values of 1 or 0 were assigned for positively and negatively observed symptoms, respectively. However, the physician was not informed the level of $\mathrm{Hg}$ concentration in the cosmetics as well as in the students' scalp hair in order to keep the objectivity of the assessment.

\subsection{Statistical Analysis}

Statistical analysis of $\mathrm{Hg}$ concentrations in the hair samples was undertaken using SPSS software, version 16. Correlations between hair $\mathrm{Hg}$ concentration and skin-lightening cosmetics usage were determined by Pearson correlation analysis, with a $p<0.05$ being considered significant. 


\section{Results}

The demographic characteristics of the students who used lightening cosmetics are presented in Table 1. All user- and control-group students were female, 19-25 years of age and attending Hasanuddin University and the Indonesian Muslim University. Student income was defined as expenditure per month. Based on the 71 USD monthly allowance of a scholarship provided by the Indonesian government for a bachelor-program student, student monthly incomes were classified as 'high' (>71 USD) or 'low' (<71 USD). The students' cosmetics usage (duration, frequency and consumption) is reported in Table 1. A minimum duration of five months of cosmetics use was considered adequate for measurement of $\mathrm{Hg}$ concentration in scalp hair. Most students (66\%) applied cosmetics to their faces one to three times per day, although the frequency of application did not necessarily correlate with the volume of cosmetics applied. Therefore, the students' cosmetics consumption was based on the weight of cosmetic cream per container used. Cosmetics consumption was classified into three groups, namely low (0-10 g/month), moderate (11-20 g/month), high (21-30 g/month) with an even distribution of students across the groups.

Table 1. Demographic characteristic of the students.

\begin{tabular}{lcc}
\hline Characteristics & Student $(\mathbf{n}=\mathbf{1 0 5})$ & Control Group (n= 43) \\
\hline Age (year) & 21.5 & 21.3 \\
Mean & 21 & 21 \\
Median & 19 & 19 \\
Minimum & 25 & 25 \\
Maximum & & - \\
\hline Duration (month) & 26 & - \\
Mean & 24 & - \\
Median & 5 & - \\
Minimum & 60 & - \\
Maximum & $19(18.1 \%)$ & - \\
\hline Frequency of use & $66(62.9 \%)$ & - \\
Once per day & $20(19.0 \%)$ & - \\
1-3 time per day & & \\
More than 3 times per day & $30(29 \%)$ & \\
\hline Cosmetic consumption & $43(41 \%)$ & $29(67 \%)$ \\
Low $(0-10$ g/month) & $32(30 \%)$ & $14(33 \%)$ \\
Moderate $(11-20$ g/month) & & \\
High (21-30 g/month) & $58(55 \%)$ & - \\
\hline Income & $47(45 \%)$ & - \\
Low income ( $<71$ USD/mo) & & \\
High income $(\geq 71$ USD/mo) & & \\
\hline
\end{tabular}

\subsection{Hair Mercury Concentration in the Scalp Hair of the Students}

Mercury concentrations in the scalp hair of cosmetics-using students were in the range of 0.5-475.9 $\mu^{-g^{-1}}$ (geometric mean $6.7 \mu \mathrm{g} \mathrm{g}^{-1}$ ), whereas the mean concentration in the control group was significantly lower at $2.3 \mu \mathrm{g} \mathrm{g}^{-1}$ (Table 2; t-test $p<0.000$ ), confirming $\mathrm{Hg}$ exposure in the students who used skin-lightening cosmetics.

The Human Biomonitoring Commission (HBMC) of the German Federal Environmental Agency [25] has released threshold limits for $\mathrm{Hg}$ (Table 3). Based on the HBMC classification, our results indicate that $60 \%$ of cosmetics-using students had 'high' levels of $\mathrm{Hg}$ in scalp hair, with $30 \%$ being at the 'alert' level. None of the control-group students had high Hg levels, with most $93 \%$ being at the alert level. 
Table 2. Mercury concentration in the scalp hair.

\begin{tabular}{lllll}
\hline \multirow{2}{*}{ Group } & \multicolumn{3}{l}{ Mercury Concentration $\left(\mu \mathrm{g} \mathrm{g}^{-\mathbf{1}}\right)$} \\
\cline { 2 - 5 } & Mean & $\begin{array}{l}\text { Geometric } \\
\text { Mean }\end{array}$ & Median & $\begin{array}{l}\text { Range } \\
(\text { Min-Max) }\end{array}$ \\
\hline Student $(\mathbf{n}=\mathbf{1 0 5})$ & 27 & 6.7 & 5.9 & $0.5-475.9$ \\
Control group $(\mathbf{n}=\mathbf{4 3})$ & 2.5 & 2.3 & 2.4 & $0.0-4.7$ \\
\hline
\end{tabular}

\subsection{Mercury Concentration in Skin-Lightening Cosmetics}

The 27 samples of the skin-lightening cosmetics used by the students were analyzed for $\mathrm{Hg}$ content (Table 4). The cosmetics originated in Indonesia, France, the USA, Japan, India, Taiwan and Germany, 18 of which were registered by the Food and Drug Administration of Indonesia and 9 were unregistered. Seven samples contained no detectable $\mathrm{Hg}$ and 20 contained $0.12-78 \mu \mathrm{g} \mathrm{Hg} \mathrm{g}^{-1}$. Ten registered cosmetics contained less $\mathrm{Hg}$ than the unregistered cosmetics. The Indonesian National Agency of Drug and Food Control (in Bahasa: BPOM) has released a concentration limit of $1 \mu \mathrm{g} \mathrm{g}^{-1}$ for $\mathrm{Hg}$ in cosmetics [26].

Table 3. Threshold limit by human bio monitoring commission of the German Federal Environment Agency.

\begin{tabular}{lll}
\hline HBM Level & Students $(\mathrm{n}=\mathbf{1 0 5})$ & Control Group $(\mathrm{n}=\mathbf{4 3})$ \\
\hline Normal $\left(<\mathbf{1} \mathrm{\mu g} \mathrm{g}^{\mathbf{- 1}}\right)$ & $9(10 \%)$ & $3(7 \%)$ \\
Alert $\left(\mathbf{1}-\mathbf{5} \boldsymbol{\mu \mathrm { g } \mathrm { g } ^ { - 1 } )}\right.$ & $32(30 \%)$ & $40(93 \%)$ \\
High $\left(>\mathbf{5} \mathbf{g ~ g}^{\mathbf{- 1}}\right)$ & $63(60 \%)$ & - \\
\hline
\end{tabular}

\subsection{Student Health Issues}

Fifteen students from each of the user and control groups were clinically examined for neurological effects and five symptoms were detected. In the user group, the detected symptom were tremor with recorded for 5 students, and 3 other students had a reduced field of vision, 2 students with slow knee-jerk and bicep reflexes, while 1 students with irregular eye movements, and 1 student unbalanced rigidity and ataxia. In the control group, three students were diagnosed with tremor and reduced field of vision with 3 students, and another three with slow knee-jerk and bicep reflexes. No cases of irregular eye movement, unbalanced rigidity or ataxia were found in this group.

\section{Discussion}

\subsection{Correlation between $\mathrm{Hg}$ in Hair and Cosmetics}

Students exposed to $\mathrm{Hg}$ in cosmetics had hair $\mathrm{Hg}$ concentrations of up to high levels. The significant positive correlation $(\mathrm{r}=0.85 ; p<0.000)$ between $\mathrm{Hg}$ exposure and concentration in cosmetics is demonstrated in Figure 2. Students who used low-Hg skin-lightening cosmetics were potentially exposed to low $\mathrm{Hg}$ concentrations, and those with higher scalp-hair $\mathrm{Hg}$ concentrations were likely to have used cosmetics with higher $\mathrm{Hg}$ contents. Hair $\mathrm{Hg}$ concentrations in the control group were lower than those of students who used skin-lightening cosmetic products. An earlier study of $\mathrm{Hg}$ in human hair and cosmetic products yielded similar results [27].

Skin absorption of $\mathrm{Hg}$ is controlled by dose, means of application (vehicle), polarity, solubility, $\mathrm{pH}$ and frequency of application [28-31]. The grouping of students according to how much (weight) cosmetic cream was used per month indicates that, with prolonged application, the $\mathrm{Hg}$ content of the cosmetics is the predominant factor that determines Hg exposure, rather than how much is used. Figure 3 indicates usage (low, moderate or high), plotted as in Figure 2 on a logarithmic scale, indicating that students at all levels of usage are distributed over all levels of HBMC classifications. This indicates no significant correlation between cosmetics consumption and scalp-hair Hg content. 
Other factors may affect $\mathrm{Hg}$ uptake, such as dietary habits, with most students consuming many types of marine fish, which are often contaminated by methylmercury that also accumulates in scalp hair. Endogenous factors may also be involved, such as anatomic variation in skin properties, age, skin health, oxidation and reduction of mercury in the skin [32]. This study relied on limited hair sample as a biomonitoring sample. For thorough examination, it is important to continue this exposure assessment using other biomonitoring samples such as blood and urine.

Table 4. Mercury content of skin-lightening cosmetics.

\begin{tabular}{|c|c|c|c|c|}
\hline No. & $\begin{array}{l}\text { Skin-Lightening } \\
\text { Cosmetic Products }\end{array}$ & Original Country & Registered & Hg Concentration \\
\hline 1 & R1 & Japan & Registered & 0.12 \\
\hline 2 & $\mathrm{R} 2$ & Indonesia & Registered & 0.35 \\
\hline 3 & R3 & French & Registered & 0.68 \\
\hline 4 & $\mathrm{R} 4$ & India & Registered & 0.84 \\
\hline 5 & $\mathrm{R} 5$ & French & Registered & 1.27 \\
\hline 6 & R6 & United States & Registered & 2.36 \\
\hline 7 & R7 & United States & Registered & 3.74 \\
\hline 8 & R8 & Taiwan & Registered & 72.25 \\
\hline 9 & R9 & Indonesia & Registered & 1895 \\
\hline 10 & R10 & Taiwan & Registered & 0.25 \\
\hline 11 & R11 & Indonesia & Registered & ${ }^{*} \mathrm{ND}$ \\
\hline 12 & $\mathrm{R} 12$ & Indonesia & Registered & 0.43 \\
\hline 13 & $\mathrm{R} 13$ & Indonesia & Registered & ${ }^{*} \mathrm{ND}$ \\
\hline 14 & R14 & Indonesia & Registered & $* \mathrm{ND}$ \\
\hline 15 & R15 & Indonesia & Registered & $* \mathrm{ND}$ \\
\hline 16 & R16 & Germany & Registered & ${ }^{*} \mathrm{ND}$ \\
\hline 17 & R17 & Indonesia & Registered & ${ }^{*} \mathrm{ND}$ \\
\hline 18 & R18 & Taiwan & Registered & ${ }^{*} \mathrm{ND}$ \\
\hline 19 & UR1 & Unknown & Unregistered & 3.41 \\
\hline 20 & UR2 & Unknown & Unregistered & 162 \\
\hline 21 & UR3 & Indonesia & Unregistered & 257.58 \\
\hline 22 & UR4 & Unknown & Unregistered & 342.59 \\
\hline 23 & UR5 & Unknown & Unregistered & 675.56 \\
\hline 24 & UR6 & Unknown & Unregistered & 1501.43 \\
\hline 25 & UR7 & Unknown & Unregistered & 1986.58 \\
\hline 26 & UR8 & Unknown & Unregistered & 5112 \\
\hline 27 & UR9 & Taiwan & Unregistered & 7834.4 \\
\hline
\end{tabular}

${ }^{*} \mathrm{ND}=$ not detected.

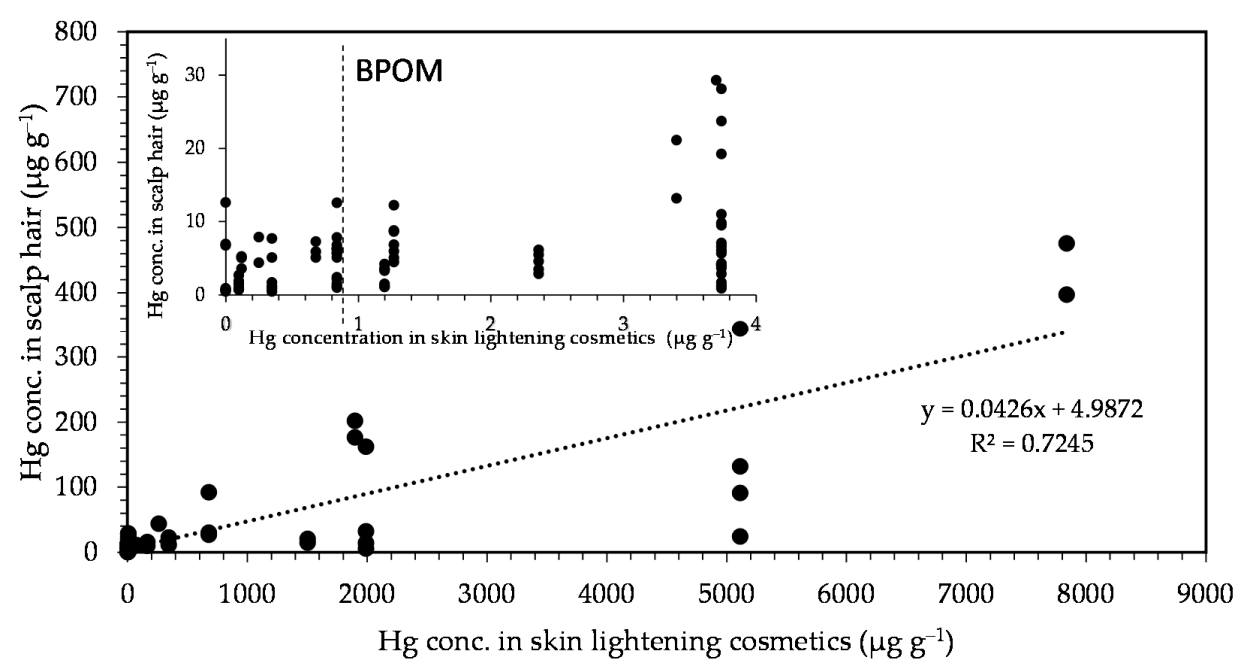

Figure 2. Correlation between $\mathrm{Hg}$ in hair and cosmetics in the students' scalp hair and cosmetics. An inserted graph is the magnification scale in the rectangular area projecting the $\mathrm{Hg}$ concentration limit in skin-lightening cosmetic products determined by BPOM. 


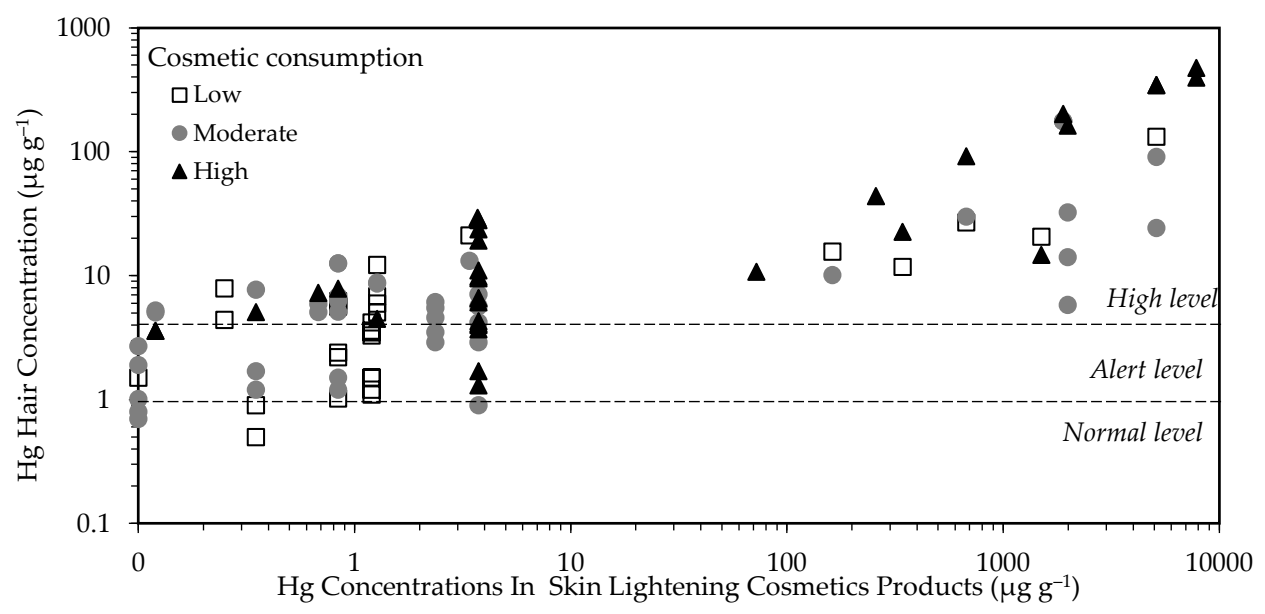

Figure 3. Correlation between $\mathrm{Hg}$ in hair and cosmetics in the students' scalp hair and cosmetics for every group of cosmetic consumptions.

\subsection{Student Health Issues}

Neurological symptoms suffered by the students cannot be associated with inorganic $\mathrm{Hg}$ toxicity from the cosmetics because the students in the control group showed a similar amount of such symptoms. The health assessment recorded 9 of the 15 user-group students who were tested displaying symptoms: two students with three symptoms, two students with two symptoms and four students with one symptom. Whereas, in the control group, there were three students with one symptom, two students with two symptoms. Only irregular eye movement, and unbalanced rigidity \& ataxia can be considered prevalent within the cosmetic-using students (<seven percent occurrences) because not any single student in the control group were suffered by those symptoms.

However, potential health issues remain as inorganic $\mathrm{Hg}$ in cosmetics may also enter the body through inhalation [33] and ingestion [12], as in the case of inhalation in gold smelting where, after working for at least five years, tremors were detected in up to $85 \%$ of cases [16].

The topical application of $\mathrm{Hg}$ compounds in cosmetics may result in $\mathrm{Hg}$ being accumulated in the kidneys [34], with a case of nephrotic syndrome reported for a 34-year-old woman who used skin-lightening cosmetic products containing 30,000 ppm Hg; her condition improved gradually after she stopping using the cosmetics [35]. Mercury in skin-lightening cosmetics may also cause skin defects such as rashes, discoloration and scarring, as well as loss of resistance to bacterial and fungal infections $[1,12,13,36]$. Mercury toxicity may also cause miscarriage, spontaneous abortion, stillbirth and low birth weight. Neonates exposed to $\mathrm{Hg}$ in utero have displayed neural tube defects, craniofacial malformations, delayed growth and other effects [37]. The mechanisms of Hg effects on the placenta and brain remain unexplained, although inorganic $\mathrm{Hg}$ does seem to cross placental and brain barriers [22,38], causing neurological disturbances [21].

Skin-lightening cosmetics are used mainly by females of reproductive age, so the awareness of possible hazardous effects on the fetus and newborns should be promoted and the quality of marketed cosmetics tightly controlled.

\section{Conclusions}

This study highlights the occurrence of $\mathrm{Hg}$ in skin-lightening cosmetics and the accumulation of $\mathrm{Hg}$ in the human body through their application. Mercury occurs at high concentrations in such cosmetics and at high or alert levels in scalp hair of users with only two prevalent symptoms, namely irregular eye movement and unbalanced rigidity \& ataxia. Students are therefore advised to change cosmetics and to monitor their health. The local government should collaborate with the Indonesian National Agency of Drug and Food Control to extend interventions by controlling the online marketing of 
cosmetic products containing hazardous ingredients. Further studies with larger samples are required for the assessment of the effects of $\mathrm{Hg}$ during pregnancy and its impact on developing babies.

Author Contributions: All authors contributed to the work presented in the manuscript. H.H.A. as the primary researcher made a substantial contribution to this work which was undertaken in association with her research. M.S. provided critical analyses and commentary during the development of the manuscript. K.S. provided the PIXE measurement of hair samples, which is also a substantial contribution to the manuscript. E.A. and N. provided investigator data. All authors have read and agreed to the published version of the manuscript.

Funding: This research was funded by Japan government for supporting this research by feasibility study "Social Acceptance of Regional Innovation for Reducing High Impact Environmental Pollution", Research Institute for Humanity and Nature (RIHN) and JSPS KAKENHI, grant number 16H02706 to M. Sakakibara.

Acknowledgments: The authors would like to thank the Universitas Muslim Indonesia and South Sulawesi of Indonesia government that has permitted to conduct research. One author (Hasriwiani Habo Abbas) would like also to thank the Indonesian government. I would like also to thank Lukmanul Hakim Arma to contribution the manuscript provide critical analyses and commentary during the development of the manuscript.

Conflicts of Interest: The authors declare no conflict of interest.

\section{References}

1. Prevodnik, A.; Willcox, A.; Lymberidi-Settimo, E.; Bender, M.; Lane, O. Mercury-Added Skin-Lightening Creams Available, Inexpensive and Toxic; European Environmental Bureau: Brussels, Belgium, 2018.

2. Kemenperin, M.H. Indonesia Lahan Subur Industri Kosmetik. Available online: https://kemenperin.go.id/ artikel (accessed on 30 June 2020).

3. Copan, L.; Fowles, J.; Barreau, T.; McGee, N. Mercury toxicity and contamination of households from the use of skin creams adulterated with mercurous chloride (calomel). Int. J. Environ. Res. Public Health 2015, 12, 10943-10954. [CrossRef] [PubMed]

4. Clarkson, T.W. The Toxicology of Mercury and Its Chemical Compounds. Toxicology 2006, 36, 609-662. [CrossRef] [PubMed]

5. Risher, J.; DeWoskin, R. Report: Toxicological Profile for Mercury; Agency for Toxic Substances and Disease Registry: Atlanta, GA, USA, 1999; pp. 1-676.

6. Mahaffey, K.R. Mercury Exposure: Medical And PublicHealth Issues. Trans. Am. Clin. Climatol. Assoc. 2005, 116, 127-154. [PubMed]

7. BPOM RI Inilah Daftar 30 Kosmetik Berbahaya, Kanker Hati Mangintai. Available online: https://metro.tempo. co/read/723535/inilah-daftar-30-kosmetik-berbahaya-kanker-hati-mangintai (accessed on 23 July 2020).

8. BPOM BPOM Kewalahan: Awas Obat Palsu. Available online: https://lifestyle.kompas.com/read/2016/11/02/ 200700523/awas.obat.palsu.ini.cara.menghindarinya (accessed on 23 July 2020).

9. World Health Organization (WHO). Mercury in Skin Lightening Products; Hinari: Geneva, Switzerland, 2011; pp. 1-24.

10. Peregrino, C.P.; Moreno, M.V.; Miranda, S.V.; Rubio, A.D.; Leal, L.O. Mercury levels in locally manufactured Mexican skin-lightening creams. Int. J. Environ. Res. Public Health 2011, 8, 2516-2523. [CrossRef]

11. Park, J.D.; Zheng, W. Human exposure and health effects of inorganic and elemental mercury. J. Prev. Med. Public Health 2012, 45, 344-352. [CrossRef]

12. Chan, T.Y.K. Inorganic mercury poisoning associated with skin-lightening cosmetic products. Clin. Toxicol. 2011, 49, 886-891. [CrossRef]

13. UNEP DTIE Chemicals Branch; WHO Department of Food Safety, Zoonoses and Foodborne Diseases. Guidance for Identifying Populations at Risk from Mercury Exposure; IOMC (Inter-Organization Programme for the Sound Management of Chemicals, Acooperative Agreement among UNEP, ILO, FAO, WHO, UNIDO, UNITAR and OECD): Geneva, Switzerland, 2008; p. 176.

14. Rafati-Rahimzadeh, M.; Rafati-Rahimzadeh, M.; Kazemi, S.; Moghadamnia, A.A. Current approaches of the management of mercury poisoning: Need of the hour. DARU J. Pharm. Sci. 2014, 22, 46. [CrossRef]

15. Syversen, T.; Kaur, P. The toxicology of mercury and its compounds. J. Trace Elem. Med. Biol. 2012, 26, 215-226. [CrossRef] 
16. Abbas, H.; Sakakibara, M.; Sera, K.; Arma, L. Mercury Exposure and Health Problems in Urban Artisanal Gold Mining (UAGM) in Makassar, South Sulawesi, Indonesia. Geosciences 2017, 7, 44. [CrossRef]

17. Yoshida, M. Placental to fetal transfer of mercury and fetotoxicity. Tohoku J. Exp. Med. 2002, 196, 79-88. [CrossRef]

18. Rusmadi, S.Z.; Norkhadijah, S.; Ismail, S.; Praveena, S.M. Preliminary Study on the Skin Lightening Practice and Health Symptoms among Female Students in Malaysia. J. Environ. Public Health 2015, 2015, 3-8. [CrossRef] [PubMed]

19. Chehimi, L.; Roy, V.; Jeljeli, M.; Sakly, M. Chronic exposure to mercuric chloride during gestation affects sensorimotor development and later behaviour in rats. Behav. Brain Res. 2012, 234, 43-50. [CrossRef] [PubMed]

20. Branches, F.J.P.; Erickson, T.B.; Aks, S.E.; Hryhorczuk, D.O. The price of gold: Mercury exposure in the amazonian rain Forest. Clin. Toxicol. 1993, 31, 295-306. [CrossRef] [PubMed]

21. Bose-O'Reilly, S.; McCarty, K.M.; Steckling, N.; Lettmeier, B. Mercury Exposure and Children's Health. Curr. Probl. Pediatr. Adolesc. Health Care 2010, 40, 186-215. [CrossRef]

22. Benz, M.R.; Lee, S.H.; Kellner, L.; Döhlemann, C.; Berweck, S. Hyperintense lesions in brain MRI after exposure to a mercuric chloride-containing skin whitening cream. Eur. J. Pediatr. 2011, 170, 747-750. [CrossRef]

23. Drasch, G.; Böse-O’Reilly, S.; Beinhoff, C.; Roider, G.; Maydl, S. The Mt. Diwata study on the Philippines 1999-Assessing mercury intoxication of the population by small scale gold mining. Sci. Total Environ. 2001, 267, 151-168. [CrossRef]

24. Marcello, M.V.; Baker, R.F. Project Protocols for Environmental and Health Assessment of Mercury Released by Artisanal and Small-Scale Gold Miners; GEF/UNDP/UNIDO: Vienna, Austria, 2004.

25. Schulz, C.; Angerer, J.; Ewers, U.; Kolossa-Gehring, M. The German Human Biomonitoring Commission. Int. J. Hyg. Environ. Health 2007, 210, 373-382. [CrossRef]

26. BPOM Republik Indonesia. Kepala BPOM RI Peraturan Kepala Bada Pengawas Obat dan Makanan Republik Indonesia Nomor 17 Tahun 2014 tentang Perubahan atas Peraturan Kepala Badan Pengawas Obat dan Makanan Nomor HK.03.1.23.07.11.6662 Tahun 2011 tentang Persyaratan Cemaran Mikroba dan Logam Berat dalam; BPOM Republik Indonesia: Jakarta, Indonesia, 2014; pp. 1-5.

27. Kinabo, C.P. Comparative Analysis of Mercury Content in Human Hair and Cosmetic Products Used in Dar Es Salaam Tanzania. Tanz. J. Sci. 2005, 31, 83-90. [CrossRef]

28. Palmer, R.B.; Godwin, D.A.; McKinney, P.E. Transdermal kinetics of a mercurous chloride beauty cream: An in vitro human skin analysis. J. Toxicol. Clin. Toxicol. 2000, 38, 701-707. [CrossRef]

29. Borowska, S.; Brzóska, M.M. Metals in cosmetics: Implications for human health. J. Appl. Toxicol. 2015, 35, 551-572. [CrossRef]

30. Lin, S.H.; Wang, X.R.; Yu, I.T.S.; Tang, W.N.J.; Li, J.; Liu, B.O.Y. Lead powder use for skin care and elevated blood lead level among children in a Chinese rural area. J. Expo. Sci. Environ. Epidemiol. 2012, 22, 198-203. [CrossRef] [PubMed]

31. Sartorelli, P.; Montomoli, L.; Sisinni, A.G. Percutaneous penetration of metals and their effects on skin. Prev. Res. 2012, 2, 158-164.

32. Hostynek, J.J. Factors determining percutaneous metal absorption. Food Chem. Toxicol. 2003, 41, 327-345. [CrossRef]

33. Held, B.; Dermatologie, C.B.-A. Chronic mercury intoxication in children of two families due to the cosmetic application of a mercury containing bleaching cream by the mothers. Akt Dermatol. 2008, 34, 274-278. [CrossRef]

34. Mckelvey, W.; Jeffery, N.; Clark, N.; Kass, D.; Parsons, P.J. Population-Based Inorganic Mercury Biomonitoring and the Identification of Skin Care Products as a Source of Exposure in New York City. Environ. Health Perspect. 2011, 119, 203-209. [CrossRef]

35. Tang, H.L.; Chu, K.H.; Mak, Y.F.; Lee, W.; Cheuk, A.; Yim, K.F.; Fung, K.S.; Chan, H.W.H.; Tong, K.L. Minimal change disease following exposure to mercury-containing skin lightening cream. Hong Kong Med. J. 2006, 12, 316-318.

36. Ladizinski, B.; Mistry, N.; Kundu, R.V. Widespread use of toxic skin lightening compounds: Medical and psychosocial aspects. Dermatol. Clin. 2011, 29, 111-123. [CrossRef] 
37. Rice, K.M.; Walker, E.M.; Wu, M.; Gillette, C.; Blough, E.R. Environmental mercury and its toxic effects. J. Prev. Med. Public Health 2014, 47, 74-83. [CrossRef]

38. De Itaituba, M.; Santos, E.O.; De Jesus, M.I.; Ildes, C.; Fróes, R. Correlation between blood mercury levels in mothers and newborns in Itaituba, Pará State, Brazil Correlação de teores de mercúrio no sangue entre mulheres e recém-nascidos do. Cad. Saude Publica 2007, 23, 622-629. 